медицина. В Будапеште в 1993 г. состоялась первая международная конференция «Фракталы в естественных науках». Проводились конференции, касаемые вопросов фрактального анализа, в частности, методы обработки фрактальных процессов в энцефалографии и кардиографии. Вышел в свет специализированный международный журнал «Фракталы», издательства Word Scientific.

\title{
Литература
}

1. Балин В.Д. Лабораторные и практические занятия к курсу психофизиологии. Учебно-методическое пособие. СПб., 2007

2. Балин В.Д. Психофизиология для психологов. Учебно-методическое пособие. С-Пб., 2008.

3. Вартанов А.В. О влиянии нарушения цветового зрения на формирование цветового семантического пространства // Психологический журнал. - 1996.-№ 2. - С . 166-170.

4. Данилова Н.Н., Фуколова Ю.В. Влияние функционального состояния на перцептивное и семантическое пространства у человека // Психологический журнал. - 1996. - № 3. - С 70- 81.

5. Измайлов Ч.А., Титова Н.А. Четырехмерное пространство восприятия эмоциональной экспрессии // Вестник Московского университета. Серия 14. Психология. 1999. - № 3. - 34.

6. Сандер Л.М. Фрактальный рост // В мире науки. - 1987. - № 3. - 62-69.

7. Свирский Я. Смысл события (на фрактальной кромке безумия) // Событие и смысл (Синергетический опыт языка). - М.: ИФ РАН, 1999. -С. 173202.

8. Симаков Ю. Рождение живых форм. В лабиринтах, теории формообразования//Знание - сила.- 1985.-№ 3 . - С . 20-21.

9. Синергетика и фракталы в материаловедении / В.С. Иванова и др. - М.: Наука, 1994.-383 с.

10. Смирнов Д. Мир образов и образ мира // Вестн. Моск. ун-та. Сер. Психология. - 1981. - № 2. - 15-29.

11. Кернберг, О. Тяжелые личностные расстройства. - М.: Класс, 2000, $464 \mathrm{c}$.

\section{ОСОБЕННОСТИ «КРИЗИСНОГО ПРОФИЛЯ» ЛИЧНОСТИ ПРЕПОДАВАТЕЛЕЙ ПРОФЕССИОНАЛЬНЫХ ОБРАЗОВАТЕЛЬНЫХ ОРГАНИЗАЦИЙ}

Журавлева Ю.А.

В научной литературе и психолого-педагогических исследованиях, посвященных проблеме психологического сопровождения образовательного процесса чаще всего рассматриваются вопросы, касающиеся воспитанников и обучающихся, сохранения их психологического здоровья, создания условий для всестороннего развития их личности, развития способностей, формировании компетенций и т.д. Говорится о субъектном подходе в образовании, о том, что дети являются активными участниками образовательного процесса, его 
субъектами. При этом на наш взгляд, недостаточно внимания уделяется другим субъектам образовательного процесса - воспитателям, учителям и преподавателям, также нуждающихся во внимании со стороны специалистовпсихологов. Именно от эффективности деятельности педагога зависит будущее ребенка, развитие его личности, раскрытие и реализация его потенциальных возможностей, способностей и потребностей.

Для исполнения возложенных на них задач воспитателям, учителям и преподавателям, как субъектам педагогического процесса необходимо обладать личностными качествами, позволяющими им самим эффективно развиваться как профессионалам, адаптироваться к изменяющимся условиям жизнедеятельности, уметь самостоятельно находить решения социально и профессионально значимых проблем, кризисов, возникающих, в том числе и в профессиональной деятельности. Таким образом, мы видим, что педагогическая деятельность требует от человека большой самоотдачи. Эта профессия всеобъемлюща по сферам приложения сил и объему требований к личности ее носителя [8, с. 5].

Кроме того, нельзя забывать и о том, что педагогическая деятельность сама по себе является достаточно стрессогенной и способна привести к профессиональной деструкции личности. В связи с этим, особую значимость приобретает проблема изучения «кризисных профилей», их влияния, как на профессиональную деятельность, так и на индивидуальные особенности педагогов.

Говоря о «кризисе» мы понимаем ситуацию, которая воспринимается и оценивается субъектом как критическая, сопровождается определенными переживаниями (конструктивными или деструктивными), требует принятия мер для ее преодоления и способная оказывать влияние на дальнейшую жизнь человека. В целях профилактики деструктивного переживания кризисов (как нормативных, так и не нормативных) нами был разработан психодиагностический комплекс, направленный на изучение «кризисного профиля» субъектов педагогического процесса - воспитателей, учителей и преподавателей. Под «кризисным профилем» нами понимается сочетание различных компонентов личности, участвующих в переживании, определяющих их глубину, формы проявлений, способствующих или препятствующих преодолению кризиса в целом. Для более полного отражения всех компонентов личности субъектов педагогического процесса участвующих в переживании, нами было использовано представление об «интегральной индивидуальности» личности, разработанное в трудах В.С. Мерлина и его школе. Интегральную индивидуальность образуют система индивидуальных свойств организма, система индивидуальных психических свойств и система социально-психологических индивидуальных особенностей [7]. В своих исследованиях C.В. Духновский предлагает использовать «расширенное» представление об интегральной индивидуальности, за счет включения в неё системы индивидуальных глубинно-психологических свойств субъекта [3], опираясь при этом на работы Л. Сонди и А.В. Смирнова [9]. 
В ходе проведенных С.В. Духновским исследований было установлено, что в переживании кризиса (острого, резкого перелома в жизни) «участвуют» перечисленные выше системы интегральной индивидуальности личности $[3,4]$.

Так для диагностики индивидуальных свойств организма нами были использованы методики, разработанные Л.В. Куликовым - «Опросник свойств темперамента» и «Доминирующее состояние» [6] (далее по тексту «ВТ» и «ДС8» соответственно).

Индивидуальные психические свойства субъектов педагогического процесса изучались с использованием методики «Шкала субъективного благополучия», разработанная Г. Перуэ-Баду, адаптированная М.В. Соколовой [1] (далее по тексту «ШСБ»), а также методики «Переживание психологического кризиса личностью», разработанную С.В. Духновским [1] (далее по тексту «ППК»).

Для изучения индивидуальных глубинно-психологических особенностей был применен модифицированный Л.Н. Собчик вариант интерперсональной диагностики Т. Лири «Диагностика межличностных отношений» [10] (далее «ДМ»).

Социально-психологические индивидуальные свойства личности изучались с помощью методик «Субъективная оценка межличностных отношений» и «Определение социально-психологической дистанции», разработанные С.В. Духновским [1] (далее по тексту «СОМО» и «СПД» соответственно).

Перейдём к описанию методики исследования и анализу наиболее значимых эмпирических данных.

В ходе исследования было проведено психодиагностическое обследование преподавателей профессиональных образовательных организаций г. Кургана и Курганской области, выборка составила 130 человек.

По своим социально-демографическим данным выборка имеет следующие характеристики: среди принявших участие в исследовании 107 лиц женского пола и 23 - мужского, в возрасте 44,1 19,5 лет, имеющие педагогический стаж $16,8 \pm 9,1$ лет. Все граждане России, прошедшие обследование по просьбе психолога.

Обратимся к описанию полученных результатов. В ходе исследования установлено, что средние показатели по шкалам методики «ППК» находятся в пределах нормы и соответствуют «кризисному профилю» личности «Психологическое здоровье». Это свидетельствует о том, что большинство опрошенных преподавателей можно отнеси к группе не переживающих кризис ( $\mathrm{n}=86$, что составило $66,2 \%$ от общего числа обследованных). На момент проведения исследования у них выявлены: высокий уровень психологической устойчивости, высокая энергичность и низкая эмоциональная восприимчивость, обеспечивающие наличие личных превентивных ресурсов адаптационно-компенсаторных способностей для конструктивного преодоления трудных жизненных ситуаций. Находясь в благоприятном психическом состоянии, испытывая чувство эмоционального благополучия, 
преподаватели данной группы способны строить гармоничные межличностные отношения, эффективно взаимодействовать с окружающими людьми, в том числе и в рамках своей профессиональной деятельности.

У другой части обследованных $(\mathrm{n}=44$, что составило 33,8 \% от общего числа обследованных) напротив, выявлены наличие переживания переломного момента в жизни (кризиса), умеренный уровень психологической устойчивости в сочетании с низкой энергичность и высокой эмоциональностью. Это свидетельствует о недостаточном уровне развития личных превентивных ресурсов - адаптационно-компенсаторных способностей для конструктивного преодоления трудных жизненных ситуаций у данной группы обследованных, в связи с чем, мы отнесли ее к категории переживающих кризис.

Средние показатели по шкалам методики «ППК» в группе переживающих кризис преподавателей соответствуют «кризисному профилю» личности «Переживание кризиса с неопределенным прогнозом». Для данного «кризисного профиля» характерно переживание переломного момента в жизни (кризиса), способствующее снижению уровня психологической устойчивости личности. Вероятны недостаточно развитая способность противостоять жизненным трудностям, недостаток веры в себя, склонность пессимистически оценивать свои перспективы. Переживание кризиса может оказывать значительное влияние и на межличностные отношения преподавателей, в том числе осуществляемые ими в рамках своей профессиональной деятельности. Возможно развитие дисгармоничных отношений между взаимодействующими субъектами, могут возникать проблемы совместимости и срабатываемости, трудности в осуществлении совместной деятельности.

Благоприятность или неблагоприятность прогноза развития личности будет определяться увеличением (или снижением) показателей «Индекса ситуационного реагирования» и «Психологическая устойчивость» методики «ППК» в соотношении друг с другом. Сохраняя прежний уровень ситуационного реагирования при повышении психологической устойчивости возможен благоприятный прогноз развития личности, при понижении психологической устойчивости возможен неблагоприятный прогноз развития личности. В данном случае благоприятность рассматривается с позиции влияния переживания кризиса на будущее преподавателя, на его психологическое и социальное благополучие.

Далее обратимся к описанию особенностей «кризисного профиля» личности преподавателей, которые по результатам тестирования по методике «ППК» отнесены к группе переживающих кризис.

Результаты диагностики индивидуальных свойств организма преподавателей переживающих кризис показали, что переживание кризиса сопровождается снижением энергичности, активности, нежеланием действовать и менять существующую ситуацию. Реализуемая же деятельность не отличается высоким темпом, а напротив, отличается сниженной скоростью выполнения действий, принятия решений и вообще осуществления каких-либо поведенческих актов. При этом обследованные данной группы сохраняют самоконтроль за своим поведением и внешними проявлениями эмоций, 
сдержанность в проявлении чувств. Им свойственна «негибкость» личности в поведении и деятельности, инертность установок, не способность уйти от шаблонов и стереотипов. Эти особенности во многом ограничивают адаптационные способности личности, не позволяют ей творчески и вариативно подходить к решению жизненных, в том числе и профессиональных задач.

Основываясь на данных, полученных по методике «ДС-8» можно сделать вывод о том, что переживание кризиса способно приводить к состоянию физической и моральной усталости, повышенной утомляемости и снижению работоспособности. У преподавателей переживающих кризис выявлен сниженный уровень активности, отсутствие веры в себя, сопровождающееся ощущением неспособности преодолевать препятствия на пути к достижению поставленных целей. Кроме того, у обследованных данной группы отмечается наличие немотивированной тревоги. Они склонны испытывать беспокойство в широком круге жизненных ситуаций, ожидать неблагоприятного исхода событий, даже если для этого нет объективных причин.

Использование методики «ШСБ» позволило оценить систему индивидуальных психических свойств переживающих кризис преподавателей. Средний показатель в данной группе соответствует умеренному уровню субъективного благополучия личности. В данном случае серьезные проблемы еще отсутствуют, но и о полном эмоциональном комфорте говорить уже нельзя. Можно предположить, что при увеличении кризисной нагрузки на личность преподавателя вероятнее всего произойдет сдвиг в сторону субъективного неблагополучия, сопровождающегося негативными эмоциональными реакциями, повышением уровня тревожности, склонностью к депрессии.

Анализ результатов изучения индивидуальных глубинно-психологических особенностей, полученных с помощью методики «ДМО» позволяет говорить о следующем. Преобладающими для группы переживающих кризис преподавателей являются «властный-лидирующий», «сотрудничающийконвенциональный» и «ответственно-великодушный» варианты межличностных отношений (I, VII и VIII октанты). «Сотрудничающийконвенциональный» и «ответственно-великодушный» типы межличностных отношений, на наш взгляд, должны быть характерными для педагогов и проявляться в их умении и стремлении найти общность с окружающими людьми, чувствовать эмоциональный настрой группы, умении подстраиваться под различные социальные ситуации, а также в доброжелательности и стремлении помочь. Можно предположить, что и преобладание «властноголидирующего» стиля также обусловлено особенностями профессиональной деятельности преподавателей, предполагающей умение организовать обучающихся, осуществлять функцию контроля, сочетать авторитарный стиль поведения с умением при необходимости оказать помощь или дать совет. Проведенные Л.Н. Собчик исследования [10] показали, что общими для личностей с данными стилями отношений являются лабильность нервной системы и повышенная эмоциональность, что в свою очередь может стать плодотворной почвой для развития деструктивного переживания кризиса. 
Социально-психологические индивидуальные свойства личности преподавателей изучались с позиции гармонии - дисгармонии межличностных отношений и наличия социально-психологической дистанции в отношениях преподавателей с субъектами педагогического процесса [2]. Анализ результатов диагностики преподавателей переживающих кризис по методикам «СОМО» и «СПД» показал следующее. Большое количество социальных контактов, которые преподаватели вынуждены поддерживать в рамках осуществления своей профессиональной деятельности, не обладают достаточной глубиной и значимостью, а напротив, имеют преимущественно поверхностный характер. Возникающие в процессе взаимодействия с субъектами педагогического процесса отрицательные эмоции или агрессивные тенденции тщательно скрываются и контролируются преподавателями, могут маскироваться под внешней гиперсоциальностью и альтруизмом. Переживание кризиса сопровождается увеличением социально-психологической дистанции в отношениях преподавателей с остальными субъектами педагогического процесса, охватывая все ее составляющие - когнитивную, коммуникативную, эмотивную и деятельностностную. В результате в отношениях преподавателей удаляющие чувства начинают преобладать над сближающими, у них может возникать недоверие и подозрительность по отношению к партнерам, утрачиваться взаимопонимание с ними, исчезать желание осуществлять какуюлибо совместную деятельность.

Обобщая полученные результаты можно сделать вывод о том, что переживание кризиса преподавателями профессиональных образовательных организаций затрагивает все стороны, рассматриваемой нами интегральной индивидуальности личности. Мы можем говорить о том, что существует ряд определенных индивидуальных особенностей личности преподавателей, которые способствуют преобладанию деструктивных переживаний кризиса и препятствуют их преодолению. Разработанный нами психодиагностический комплекс позволяет диагностировать данные особенности личности, строить на их основе «кризисный профиль» личности преподавателей и на его основе разрабатывать комплекс мер по профилактике деструктивных переживаний кризиса.

\section{Литература}

1. Духновский С.В. Диагностика межличностных отношений. Психологический практикум. - СПб: Речь, 2010. - 141 с.

2. Духновский С. В. Психология отношений личности: монография. Курган: Изд-во Курганского гос. ун-та, 2014. - 380 с.

3. Духновский С.В. Кризис и его переживание личностью: результаты эмпирического исследования // Вестник Костромского государственного университета им. Н.А. Некрасова. Серия: «Педагогика. Психология. Социальная работа. Ювенология. Социокинетика». - Кострома, 2015. - № 2. T.21. - С.30-35.

4. Духновский С.В., Журавлева Ю.А. Соотношение «кризисного профиля» личности с типом психосоматической патологии//Бюллетень науки и практики. Вып. 1. Сб./ Ред.-сост. Е.С. Овечкина. - Нижневартовск, 2016. - №1 - С. 43- 49. 
5. Журавлева Ю.А., Духновский С.В. Особенности дистанции в межличностных отношениях воспитателей дошкольных образовательных учреждений переживающих и не переживающих кризис//Успехи современной науки и образования. Белгород, 2017. №2. Т.6. С. 51-57.

6. Куликов Л.В. Психогигиена личности. Вопросы психологической устойчивости и психопрофилактики: Учебное пособие. - СПб: Питер, 2004. $464 \mathrm{c}$.

7. Мерлин В.С. Очерк интегрального исследования индивидуальности. М.: Педагогика, 1986. -256 с.

8. Овчарова Р.В. Психологическая фасилитация работы школьного учителя: учебное пособие. - М.: ИЗД-ВО Артикул, 2007. - 305 с.

9. Смирнов А.В. Екатеринбургские лекции по экспериментальной диагностике побуждений Леопольда Сонди: Учебное пособие. Екатеринбург: Университет, 2005. - $256 \mathrm{c.}$

10. Собчик Л.Н. Диагностика межличностных отношений. Модифицированный вариант интерперсональной диагностики Т. Лири: методическое руководство. - Вып. 3. - М.: Московский кадровый центр при ГУ по труду и социальным вопросам Мосгорисполкома, 1990. - 48 с.

\section{ОРГАНИЗАЦИЯ И ФУНКЦИОНИРОВАНИЕ ПОВСЕДНЕВНОГО ДИСКУРСА* \\ Зачесова И.А., Гребенщикова Т.А., Афиногенова В.А., Кубрак Т.А.}

Речевая практика является неотъемлемой частью жизни каждого человека. Ежедневно каждый из нас читает книги, газеты, журналы, слушает радио, смотрит различные телепрограммы и обращается к Интернету. Но какую бы роль в современном мире ни приобретал масс-медиа дискурс, СМИ едва ли могут соперничать по распространенности, многообразию форм, значимости в жизни человека с дискурсом повседневно-бытовым. Разговоры дома и на улице, в гостях, в транспорте и магазине - ежедневно каждый из нас выступает участником повседневного бытового дискурса. Именно повседневный дискурс является базовой, генетически и исторически исходной формой дискурса. С ранних лет жизни, едва освоив первые слова, и до конца дней человек остается участником повседневного дискурса. Очевидно, что особенности организации повседневного диалога связаны с текущим состоянием партнеров коммуникации, а ход его развития - со складывающимися в разговоре отношениями собеседников. «Подвижная» эмоциональная дистанция, непринужденный характер повседневного дискурса, его «принципиальная незаданность» дают собеседникам большую степень «интенциональной свободы», тогда как интенциональная организация других видов дискурса в большой мере определяется их базовой целевой направленностью, коммуникативной стратегией, которая выступает доминантой, своего рода «гипер-интенцией» по отношению к интенциональным составляющим дискурса. В совокупности перечисленные особенности повседневного общения, 